\title{
Performances of Community Schools towards Students' Learning and Satisfaction: A Case of Makawanpur and Udayapur Districts
}

\author{
Dr. Bijaya Nepal \\ Lecturer and Campus Chief, Hatiya Janapriya Multiple Campus, Nepal \\ Email: drbijayanepal@gmail.com
}

\begin{abstract}
This study was undertaken to analyses the performances of community schools towards students' learning and satisfaction in Makawanpur and Udayapur Districts of Nepal. School performances evaluation, observation tools were used to measure the input, process and output condition of selected schools for the research. This study was conducted from February 2019 to March 2020. The sample size was taken by using cluster sampling method. There were 203 numbers of senior secondary schools in the study area; among them (13.6\%) senior 28 secondary schools were taken from both districts. Analysis of the data was done by using SPSS version 20 and the Multiregression and correlation test was applied to analyze the data.
\end{abstract}

Keywords: Students Learning and Satisfaction, Schools Performance

\section{Introduction}

School plan is a key part of school management. Planning determines the physical, environmental and educational process of the school system. It protects the physical and mental health of the students studying in the school and teachers, as well as other stakeholders (Mulford, 2003). The management of school facilities is a process that assists in the operation of the organization's buildings and other technical systems. A school plan is also a physical plan for achieving real educational goals and objectives (Charles, 2003). The school plan includes educational and non-educational activities, including site selection for the establishment of new schools, design and construction of buildings, maintenance and modernization of old buildings(Asiabaka, 2008, pp. 29).

As school planning is an important part of school management, it manages the physical and environmental aspects of the school, providing students with conducive learning environment and helps them achieve their best academic results. The systematic planning of the school not only helps to improve the academic achievement of the students, but also helps to increase the satisfaction of the students towards the school (Beatriz Pont, 2008). 
School leadership, act as a key mediator between students, teachers and the school environment, a task that is only possible with efficient leader. Only successful leadership can coordinate all activities of school management, such as investment (physical facilities and human resources), process (teaching-learning process and extracurricular activities) and achievement (student advancement, achievement and satisfaction). Leadership can contribute to improve students' learning by adapting to the conditions and weather within the school and with maintaining personal and institutional coordination. School leadership can act as a bridge between internal school reform processes (pp. 15-17).

According to Parajuli and Das (2013), studying various literatures, it is found that the educational and physical condition of community schools in Nepal has not improved yet. There are three major problems faced by community schools in Nepal. These are listed as follows: Problems related to physical infrastructure, educational quality and efficient leadership (pp. 150-53). Travis (2010), highlighted that, school buildings, classrooms, playgrounds, libraries, gardens, student relationships, school environments, etc. affect the learning environment of students. Architects believed that, schools' design affects students' learning rate and mind set. Therefore, the overall system of the school should be developed in an integrated way. An integrated school development plan helps to broaden the level of consciousness and activity of teachers and parents over time, and can increase student satisfaction by improving the learning environment (pp. 1-9).

Wright \& Lesisko (2010) highlighted that the construction and improvement of school infrastructure during school hours may affect the learning environment, the psychological condition and health condition of the students, which can cause problems even in schools' operation of the schools' administration and results in students' discontent. Therefore, it is suggested not to manage the construction of the school and other infrastructures while the educational program is running. In particular, such works are still conducted mostly by the management of rural schools as compared to urban schools. In order to improve students' learning achievement, administrators must complete all management tasks before starting the school program (p. 13).

According to UNICEF, (2010) Child Friendly School means that any school has fulfilled the minimum requirements under the Child Friendly Index; 1) Quality 
education for children studying in school, 2) Appropriate management of school buildings, classrooms, playgrounds, libraries, toilets, gardens etc. 3) Health and safety within the school premises as well as emotional protection of children, psychological, and physical well-being and responsible environment, 4) Relationships between students, families and communities to create children's abilities, 5) Competent school policy, management and equal participation of children in all activities etc. It is believed that if children are provided conducive environment in all respects, their satisfaction will increase and learning achievement will be improved. The only such schools can be categorized as the best school (p. 7).

\subsection{Performance of Nepalese Community}

According to Nepal \& Maharjan, (2015), the educational performances of Nepalese community schools are weak in the international competition. The performance of a community school is weaker as compared to institutional schools because of incompetence, absenteeism, lack of responsibility and accountability. The SLC Examination is the key indicator of secondary level schools' academic outcome. The Government's investments in community school are increasing trend, but the outcome of Nepalese secondary education is turning down day by day. It deteriorated the community faith in community schools in Nepal (pp. 266-279). Government plans for education have continually failed in spite of extensive educational intervention. Community schools are commonly associated with low achievement, poor infrastructure, low quality teaching, weak management and limited financing (Thapa, 2011, pp. 30-32).

Most of the schools' infrastructure condition and provision of education was poor, around 80 per cent community school and 20 per cent institutional schools' performance was insufficient. Using basic 14 key indicators of the schools' physical condition it was found that only about 25 per cent of community schools had somehow better conditions (CERID, 2002, p. 47). The community schools in the Nepal have used only the textbooks, which indicates that they have been running in a conventional way. Schools are required to be a child friendly learning environment for the creation of better learning environment (DOE, 2011, p. 7).

The overall quality of community schools is weak, 65 per cent community schools have inadequate classrooms, laboratories and workshops, libraries, toilet, sports facilities, etc. There are no strong policies and guidelines for school development 
from the side of Government in Nepal. Although basic education is free and accessible for all in community schools, students' enrollment towards community schools is deteriorating whereas in institutional schools it is increasing day by day because of quality education. The students' outcome of community schools is in decreasing trend, while the Government's investment is increasing year by year (Nepal, 2016).

The Government of Nepal has conducted performance testing since 2011 to study the overall condition of community schools and improve them. Thus far, the Ministry of Education, Science and Technology has tested the performance of community schools in more than 60 districts. This study covers some representative parts of the performance testing program of these schools. The main objective of this study is to analyze the performance of community schools towards students' learning achievement and satisfaction in Nepal.

\subsection{Conceptual Frame}

Any research study needs to be based on theory and philosophy. If, in the past, researchers have originated a model that is consistent with this study, the research can be taken as a reference (Vandiver, 2011). The CIPP model (Investment/Input, Process and Product/Output) formulated by Daniel Stufflebem seems to be very useful for school performance studies. This model helps to improve the weaknesses by evaluating the school's performance level (pp. 200-215). Since the CIPP model appears to be appropriate in this study as well, the related conceptual framework is discussed here.

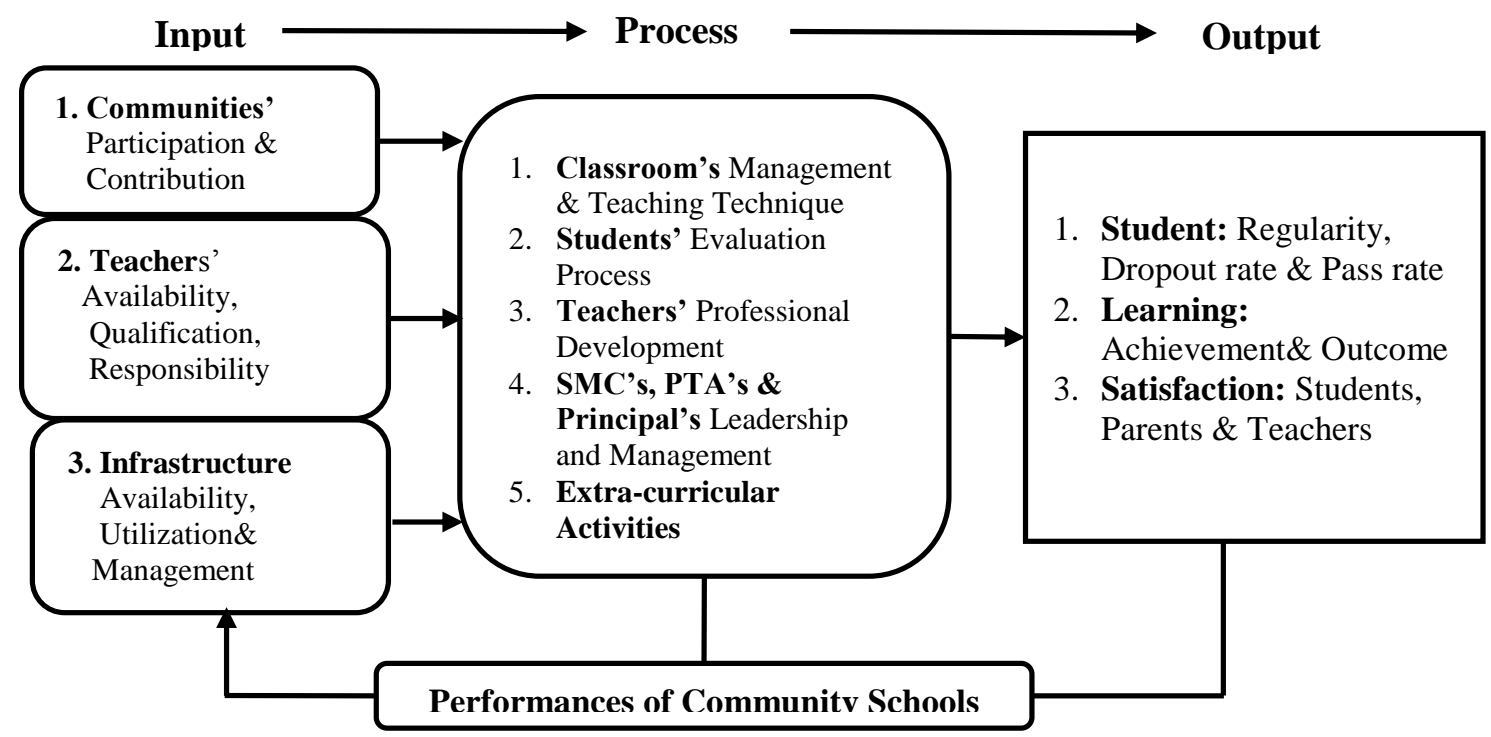

Figure 1: Conceptual Framework (Researchers Self Made) 
There are three types of study variables that included in this study where, input (independent variables) means investment related variables, process (moderator variable) indicates schools' activities related variables and output (dependent variables) means the outcome of school. Detail list of these variables are given below:

\section{A. Independent Variable:}

Input (Investment of Community Schools)

1. Available Infrastructures, Utilization \& Management

2. Available Teachers, Qualification, Responsibility

B. Moderator Variables:

Process: (Activities of Community Schools)

1. Community Participation \& Contribution

2. Classroom Management \& Teaching Technique

3. Students Evaluation Process

4. Teachers' Professional Development

5. SMC, PTA \& Principal Leadership and Management

6. Extracurricular Activities

C. Dependent Variables:

Output (Performances of Community Schools)

1. Student Regularity, Dropout rate \& Pass rate

2. Learning Achievement \& Outcome

3. Students, Parents \& Teachers' Satisfaction

\section{Method}

Descriptive and analytical research designs were used and cross-sectional data was collected to analyze the performance of community schools towards students' learning achievement and satisfaction in Nepal. This study was related to researcher's observational analysis regarding the performance of community schools. So, the only observation tools were used to collect information. This research was conducted using cluster sample selection methods. The target area of the study was Makawanpur and Udayapur districts of Nepal, where the research was conducted. The two selected districts were divided into 28 clusters on the basis of ecological belt. Out of these 28 clusters, only four clusters were selected as study areas. There were 203 senior secondary schools in the selected districts. Out of which, 13.79 percent (28) senior secondary schools were included in this study. The study programme was conducted in all the 28 senior secondary schools in the four selected clusters. 


\section{Analysis and Interpretation}

School performance results were measured at four levels. In the results evaluated, the schools with 40 percent or less marks were declared poor, the schools with 41 to 70 marks were given fair, the schools with 71 to 90 marks got good and the school with more than 91 marks got the excellent standard.

Table1: Comparative Performance Report of the Study Area

\begin{tabular}{c|cccc|cccc}
\hline \multirow{2}{*}{ District Wise } & \multicolumn{3}{|c|}{$\begin{array}{c}\text { Selected Schools of Udayapur } \\
\text { District's }\end{array}$} & \multicolumn{3}{c}{$\begin{array}{c}\text { Selected Schools of Makawanpur } \\
\text { Pistrict's }\end{array}$} \\
& & \multicolumn{3}{c}{$\begin{array}{c}\text { Performance Report } \\
\text { Performance Report }\end{array}$} \\
\hline Ranking & Input & Process & Output & Average & Input & Process & Output & Average \\
\hline Poor & 0.0 & 0.0 & 10.7 & 3.6 & 0.0 & 0.0 & 3.6 & 1.2 \\
Fair & 39.3 & 35.7 & 17.9 & 31.0 & 28.6 & 39.3 & 39.3 & 35.7 \\
Good & 10.7 & 14.3 & 14.3 & 13.1 & 21.4 & 10.7 & 7.1 & 13.1 \\
Excellent & 0.0 & 0.0 & 7.1 & 2.4 & 0.0 & 0.0 & 0.0 & 0.0 \\
\hline
\end{tabular}

The results in the above table shows, only 7.1 per cent of the schools in Udayapur district achieved excellent results in terms of output. Where the community schools of Makawanpur district have not achieved excellent results. Similarly, both districts' community schools have not achieved excellent results in terms of investment (Input) and the process. It means that the performance level of community schools was not excellent. Among them, 35.7 per cent of the rural schools in Makwanpur district have normal results. However, the results of 31 per cent schools in Udayapur district were also normal. This means that the performance level of most of the schools was found to be normal. Although, the investment condition of 21.4 per cent of the rural schools in Makwanpur district is good, the output seems to have decreased due to decline in the process.

Given result shows that the schools' of Makwanpur District have given the same priority $(50 \%)$ to the school learning environment as well as teaching-learning activities (Process activities), along with Udayapur District's schools. Similarly, Makwanpur District has also given the same priority (50\%) on schools' input variables (infrastructure, teachers and community participations).

Table2: Comparative Correlation ( $r$ - value) Performance Report of the Study Area

\begin{tabular}{c|cc|cc}
\hline \multicolumn{2}{c|}{ Selected Schools of Udayapur District's } & \multicolumn{2}{c}{ Selected Schools of Makwanpur District's } \\
\hline Indicator & Input & Process & Input & Process \\
\hline Process & 0.99 & & 0.89 & -0.99 \\
Output & -0.89 & -0.93 & -0.81 & \\
\hline
\end{tabular}


The correlation between investment and process of schools in Udayapur district is 0.99 , while the correlation between investment and production is -0.89 . However, the relationship between school investment and process in Makawanpur district is 0.89 , due to which the result of Makawanpur district is zero. This means that the school that performs better in the process than in the investment can bring better result. The correlation between investment and outcome and the correlation between process and outcome of schools in both the districts seems to be highly negative. The high negative correlation between the variables means that the investment and process in the school do not seem to have a positive effect on outcome.

Table3: Regression analysis

\begin{tabular}{|c|c|c|c|c|c|c|}
\hline \multicolumn{7}{|c|}{ Model Summary $^{\mathbf{b}}$} \\
\hline $\begin{array}{c}\text { Model- } \\
1\end{array}$ & $\mathrm{R}$ & $\begin{array}{c}\mathrm{R} \\
\text { Square }\end{array}$ & $\begin{array}{l}\text { Adjusted R } \\
\text { Square }\end{array}$ & $\begin{array}{c}\text { Std. Error of the } \\
\text { Estimate }\end{array}$ & Sig. F & Durbin-Watson \\
\hline & $.902^{\mathrm{a}}$ & .814 & .686 & 7.559 & .001 & 2.016 \\
\hline
\end{tabular}

\section{a. Dependent Variable:}

Output (Performances of Community Schools)

- Student Regularity, Dropout rate \& Pass rate

- Learning Achievement \& Outcome

- Students, Parents \& Teachers Satisfaction

\section{b. Independent Variable: Predictors}

Input (Investment of Community Schools)

- Available Infrastructures, Utilization \& Management

- Available Teachers, Qualification, Responsibility

Process: (Activities of Community Schools)

- Community Participation \& Contribution

- Classroom Management \& Teaching Technique

- Students Evaluation Process

- Teacher Professional Development

- SMC, PTA \& Principal Leadership and Management

- Extracurricular Activities

This table provides the $R, \mathrm{r}^{2}, R^{2}$, sig. $\mathrm{F}$ and Durbin-Watson values. The $R$ value represents the simple correlation, in " $\mathrm{R}$ " Column $\mathrm{R}=0.902$, which indicates a high degree of correlation. The " $r^{2}$ " R-Square column $r^{2}=0.814$, it indicates the intensity of the total variation in the dependent variable; the students' outcome can be explained by the independent variables; input, process and output. In this case, $81.4 \%$ can be explained, which is large. Researcher found that the adjusted " $\mathrm{R}^{2 \text { " value is }}$ $0.686\left(\mathrm{R}^{2}=68.6 \%\right)$. This means that the linear regression explains $68.6 \%$ of the variance in the data. The Durbin-Watson $d=2.016$, which is an internal role for the performance of community schools and negative auto correlation between the two 
variable. Therefore, the researcher can assume that there is first order negative linear auto-correlation in this multiple linear regression data.

\section{Conclusion}

In the conclusion, the schools' of Makwanpur District have given the same priority to the school learning environment as well as teaching-learning activities (Process activities), infrastructure, teachers and community participations (investment activities) along with Udayapur District's schools, 7.1\% community schools of Udayapur District have achieved excellent result in the field of students' satisfaction and achievement (output variables), but community schools of Makwanpur District have not achieved excellent result. So, the overall results concluded that, Udayapur District's rural areas community schools were better than Makwanpur District. The correlation between input variables and process variables with the output variables (educational achievement and satisfaction of students) of schools in both the districts seems to be very negative, while the correlation between input and process seems to be very positive. Overall results indicate that, students' academic achievement and satisfaction have deteriorated due to weakness in investment and processes. The high negative correlation among the variables means that the investment and process in the school do not seem to have a positive effect on production.

\section{References}

Asiabaka, T. P. (2008). The need for effective facility management in schools in Nigeria. New York Science Journal, 1(2), 10-21. Retrieved Feb 14, 2014, from http://www.sciencepub.org

Beatriz Pont, D. N. (2008). Improving School Leadership. OECD publications. Retrieved from http://www.oecd.org/publishing/corrigenda

Nepal, B. \& Maharjan. P. D., (2015). Effect of School's Physical Facilities on Learning and Outcomes of Students in Nepal. Journal for Studies in Management and Planning, 266-279. Retrieved from http://internationaljournalofresearch.org/

Cash, C., \& Twiford, T. (2010). Improving student achievement and school facilities in a time of limited funding. Blacksburg: The Connexions Project. Retrieved Dec 24, 2014, from http://cnx.org/content/m23100/1.2/

CERID. (2002). School effectiveness in Nepal: A synthesis of indicators. Tribhuvan University. Kathmandu, Nepal: Centre for Educational Research Innovation and Development.

Charles, V. (2003). Education Management Information System (EMIS) and the formulation of Education for All (EFA): plan of action, 2002-2015. Tajikistan: UNESCO Office 
Almaty, Tajikistan, Ministry of Education. Retrieved from https://unesdoc.unesco.org/ark:

DOE. (2011). School level educational statistics of Nepal consolidated report (2068 BS). Sanothimi, Bhaktapur: Government of Nepal Ministry of Education Department of Education.

Lin, M.-D. (2012). Cultivating an environment that contributes to teaching and learning in schools: High school principals' actions. Peabody Journal of Education, 87(2), 200215. doi:10.1080/0161956X.2012.664467

Mulford, B. (2003). SCHOOL LEADERS: CHALLENGING ROLES AND IMPACT ON TEACHER AND SCHOOL EFFECTIVENESS. OECD. Retrieved from https://www.oecd.org/education/school

Nepal, B. (2016). Relationship between the condition of school's infrastructure facilities, learning environment and students' outcomes. International Journal for Research in Social Science and Humanities Research, 2(5), 44-57.

Raj, D., Parajuli, T., \& Das. (2013). Performance Of Community Schools In Nepal: A Macro Level Analysis. INTERNATIONAL JOURNAL OF SCIENTIFIC \& TECHNOLOGY RESEARCH, 2(7), 148-154. Retrieved from http://www.ijstr.org/final-print

Thapa, A. (2011). Does private school competition improve public school performance? The case of Nepal. Graduate School of Art and Science. New York: Columbia University. Retrieved Dec 10, 2014, from http://academiccommons.columbia.edu/download/fedora_content/download/ac:13230 6/CONTENT/Thapa_colu..

UNICEF. (2010). A study on Child Friendly School (CFS) Initiatives and its effects on school functioning in Nepal. Kathmandu: UNICEF, Nepal. Retrieved from http://www.doe.gov.np

Vandiver, B. (2011). The impact of school facilities on the learning environment. Taxas: Capella University. Retrieved Jan 20, 2013, from http://gradworks.umi.com/34/39/3439537.html

Wright, R. J., \& Lesisko, L. J. (2010, April 30- May 4 5). Stress and the administrator of rural schools being rebuilt. Paper presented at the Annual Meeting of the American Educational Research Association, p. 13. Retrieved Dec 23, 2014, from http://www.eric.ed.gov/PDFS/ED511662.pdf 